\title{
COMPARATIVE STUDY BETWEEN LONG AND SHORT TERM ESTROUS SYNCHRONIZATION PROTOCOLS ON ESTROUS AND FERTILITY RESPONSES OF CYCLIC EWES
}

\author{
HOWIDA M.A. ABD-EL-RAHMAN ${ }^{1}$ and MAHA A. IBRAHIM ${ }^{2}$ \\ ${ }^{1}$ Field Investigation Department, Animal Reproduction Research Institute, Giza, Egypt. \\ ${ }^{2}$ Biology of Reproduction Department, Animal Reproduction Research Institute, Giza, Egypt.
}

Received: 28 June 2018; Accepted: 30 July 2018

\begin{abstract}
The present study was undertaken to minimize the period over which the progesterone impregnated sponges used for estrous synchronization protocols from 12 days to only 7 days, for improving conception rate and assess the serum hormonal concentrations, protein profile changes as well as oxidant- antioxidant status to compare short term with long term protocol in cyclic Barki ewes. Twenty multiparous cycling ewes $(2-4$ years old) were randomly assigned into two equal groups (10 each), the first group was the short term protocol group (S-term protocol) and treated with sponges containing $50 \mathrm{mg}$ medroxy progesterone acetate (MAP) for 7days. The second group was the long term protocol group (L-term protocol), also treated with the same sponges but for 12 days. At the time of sponge withdrawal, all ewes were intramuscularly injected with 200 IU PMSG (Pregnant Mare Serum Gonadotropin). Four fertile rams were introduced to all the ewes in the two groups for estrus detection and natural mating on the day of sponge withdrawal. Blood samples were collected on day of sponge insertion; on the $4^{\text {th }}$ day, the $6^{\text {th }}$ day of insertion; on the day of sponge withdrawal; on the $2^{\text {nd }}$ day of withdrawal as well as at one month after withdrawal from both groups. Conception rate as well as lambing rate were significantly higher $(\mathrm{P}<0.05)$ in $\mathrm{S}$-term protocol $(90 \%)$ than in L-term protocol group $(60 \%)$. Serum progesterone level was significantly $(\mathrm{P}<0.05)$ higher in $\mathrm{S}$-term protocol than L-term protocol group on day of withdrawal and during the first month after withdrawal $(1.97 \pm 0.08$ vs $1.34 \pm 0.10$ $\mathrm{ng} / \mathrm{ml})$ and $(2.78 \pm 0.15$ vs $1.89 \pm 0.17 \mathrm{ng} / \mathrm{ml})$, respectively. There was a significant decrease $(\mathrm{P}<0.05)$ in MDA level on the $2^{\text {nd }}$ day of withdrawal and at one month after withdrawal in S-term protocol ewes than Lterm protocol $(10.17 \pm 0.25,9.02 \pm 0.22$ and $12.45 \pm 0.54,9.75 \pm 0.22 \mathrm{nmol} / \mathrm{ml})$ ), respectively. Short-term progestagen protocol ( 7 days) for estrus synchronization resulted in an improved fertility than the common long-term protocol (12 days) in adult cyclic ewes.
\end{abstract}

Key words: Synchronization, progestagen, protein, antioxidants, ewes.

\section{INTRODUCTION}

The estrus synchronization technique is an important management technique that has been used to improve the reproductive efficiency of sheep and goats (Abecia et al., 2012). Progestagens are widely used to synchronize estrus (Evans, 2001). Intravaginal sponge impregnated with progestogens being the most commonly used for estrus synchronization in sheep (Manes et al., 2010 and Abecia et al., 2012), as it provide estrus synchronizaion by extending the luteal phase during the treatment period in ewes (Wildeus, 1999; Whitley and Jackson 2004). The common applied progestagen treatment for oestrous synchronization in ewes lasts 12-14 days, a time period similar to the lifespan of a cyclic corpus luteum

Corresponding author: Dr. MAHA A. IBRAHIM E-mail address: maha_doctor2013@yahoo.com Present address: Biology of Reproduction Department, Animal Reproduction Research Institute, Giza, Egypt.
(Abecia et al., 2012), followed by intramuscular (IM) injection of equine Chorionic Gonadotropin (eCG) appear to be the most practical method for estrus synchronization in ewes (Gomez et al., 2006; Swelum et al., 2015). However, this common treatment with a prolonged time of administration has been found to have detrimental effects on conception rate (Martin et al., 2004) due to ovulation of aged follicles (Johnson et al., 1996; Viñoles et al., 2001).

So, as long time progesterone applications have had suppressive effects on fertility and thus short period progesterone applications have been suggested as an alternative (Vinoles et al., 2001; Ali, 2007; Husein et al., 2007), because short-term protocols possibly allow for facilitating the managerial tasks, minimizing the vaginal discharge and infection risks and thus increasing the fertility rates. During different physiological periods, protein as a nutrient is an essential component for the female during her life; Serum protein is essential biochemical parameter for reproduction because it plays major role in 
embryogenesis and gametogenesis. (McBurney et al., 2002).

Oxidative stress alters the endocrine status, duration of estrus, follicular growth and development, and early embryonic development, all of which have detrimental effects on fertility (Fuquay, 1981; Dobson et al., 2012). The impacts of oxidative stress on the reproductive efficiency of live-stock are well documented (Ayo et al., 1996; Dobson et al., 2012). Using exogenous progesterone during synchronization increases lipid oxidation (Sönmez et al., 2009).

Our goal was to minimize the period over which progestagen sponges are inserted, from 12 days to only 7days to produce good results in establishing oestrus and improving conception rate and assess the serum hormonal concentrations. Protein profile changes and oxidant- antioxidant status on different days of the synchronization were followed up during both the short and the long term synchronization protocols for Barki ewes in breeding season.

\section{MATERIALS AND METHODS:}

The present study was performed at the experimental farm of Animal Reproduction Research Institute (ARRI). Twenty multiparous cycling Barki ewes (2 4 years old) were selected randomly from the flock and used in the present experiment. All ewes were healthy and clinically free from external and internal parasites. Animals housed in semi open pens under natural day light and temperature.

According to standard farming practice of ARRI, the animals were fed twice a day and had free access to drinking water and mineral blocks. They were fed with good-quality Egyptian clover, barseem (alfa alfa) every day and were offered a standard total mixed ration according to NRC (2007).

\section{Animal groups and treatment protocols:}

Before the start of the experiment, ewes were examined by ultrasound scanner (200 pie Medical Co - Nertherland - Holand), to confirm that ewes were non-pregnant.

Ewes were randomly assigned to two equal groups (10 each), the estrous cycles of all ewes were synchronized as follow: the first group (Short term protocol group) S-term protocol group, treated with sponges containing $50 \mathrm{mg}$ medroxy progesterone acetate (MAP) which inserted intravaginally for 7days. The second group (Long term protocol group) L-term protocol group, treated with the same sponges but for 12 days. All ewes were injected with 200 IU PMSG at the time of sponge withdrawal.

\section{Estrus detection and mating:}

Four fertile Barki rams with good body conditions score were introduced to the ewes, two for each experimental group for estrus detection and mating; starting on the sponge withdrawal day. Rams were allowed to rotate among different ewes in the two groups to avoid sire/group confounding effect.

\section{Measured traits throughout the experimental period:}

Fertility was monitored in terms of conception rate, and lambing rate, all data was statistically analyzed using Costat program.

\section{Conception rate $=$}

number of conceived ewes / number of mated ewes x 100 . (Ozyurtlu et al., 2011)

\section{Lambing rate $=$}

number of lambing ewes / number of mated ewes x 100.

$$
\text { (Zeleke et al., 2005) }
$$

\section{Blood samples:}

Blood samples were collected from the jugular vein in the early morning on day of insertion (day of sponge insertion); on the $4^{\text {th }}$ day, the $6^{\text {th }}$ day of insertion; on the day of withdrawal (day of sponge withdrawal); on the $2^{\text {nd }}$ day of withdrawal as well as at one month after withdrawal and ewes breeding from both groups. Whole blood was placed in a plain centrifuge tubes for serum separation. Serum was stored at $-20^{\circ} \mathrm{C}$ till assay of progesterone, estradiol, and some biochemical parameters [total protein (TP), albumin (Alb.)] and antioxidant status parameters (glutathione peroxidase (GPX) and malondialdehyde (MDA).

\section{Hormonal and biochemical analyses:}

Hormones were assayed using ELISA kits (Monobind Inc. Lake forest, CA 92630, USA): progesterone (P4) Ross et al. (1981); estradiol (E17ß) Ratcliffe et al. (1988). Total protein (TP) (Doumas et al., 1981), albumin (Doumas et al., 1971), and globulin was calculated by substracting the albumin values from the total protein values (Eckersall, 2008), glutathione peroxidase (GPX) Pagila and Valentine (1967) and Malondialdehyde (MDA) (Ohkawa et al., 1979) by colorimetric method.

\section{Statistical analysis:}

Results are expressed as mean \pm standard error (SE). Differences between means in different groups were tested for significance using a one-way analysis of variance (ANOVA) followed by Duncan's test, conception and lambing rates data were subjected to statistical analysis by Microstate copy right (c) 1984; Eco soft, Inc. employing a completely randomized design according to Snedecor and Cochran (1982).

\section{RESULTS}

Conception and lambing rates of S-term protocol and L-term protocol groups were represented in table (1), conception and lambing rates were significantly higher $(\mathrm{P}<0.05)$ in $\mathrm{S}$-term protocol group than that in L-term protocol group ( $90 \%$ vs $60 \%$ ), respectively. 
Table 1: Conception and lambing rates of Barki ewes after synchronization by short and long term protocols $(n=10)$.

\begin{tabular}{ccc}
\hline Groups & Conception rate & Lambing rate \\
\hline $\mathbf{S}-$ term & $(9 \backslash 10) 90 \%^{\mathrm{a}}$ & $(9 \backslash 10) 90 \%^{\mathrm{a}}$ \\
\hline $\mathbf{L}-$ term & $(6 \backslash 10) 60 \%^{\mathrm{b}}$ & $(6 \backslash 10) 60 \%^{\mathrm{b}}$ \\
\hline
\end{tabular}

Data with different superscripts within the same column are significantly different at $(\mathrm{P}<0.05)$.

In the present study, the progesterone level in S-term protocol group, was significantly $(\mathrm{P}<0.05)$ increased after sponge insertion and reached peak level $(6.00 \pm$ 0.19 and $5.70 \pm 0.22 \mathrm{ng} / \mathrm{ml})$ on the $4^{\text {th }}$ and on the $6^{\text {th }}$ days of insertion after that it significantly $(\mathrm{P}<0.05)$ decreased to reach $(1.97 \pm 0.10 \mathrm{ng} / \mathrm{ml})$ on the day of withdrawal (day 7), and continued decreasing tell reached the minimal level on the $2^{\text {nd }}$ day of sponge withdrawal, after that it began to increase again during the first month after withdrawal. Similar trend was also noticed in ewes of L-term protocol group, and its levels were $(5.86 \pm 0.24 ; 5.67 \pm 0.22 ; 1.30 \pm$ $0.0 ; 0.40 \pm 0.03$ and $1.89 \pm 0.16 \mathrm{ng} / \mathrm{ml})$ on the $4^{\text {th }}$ and the $6^{\text {th }}$ days of insertion; day of withdrawal (day 12); the $2^{\text {nd }}$ day of withdrawal and during the first month after withdrawal, respectively (Fig. 1).

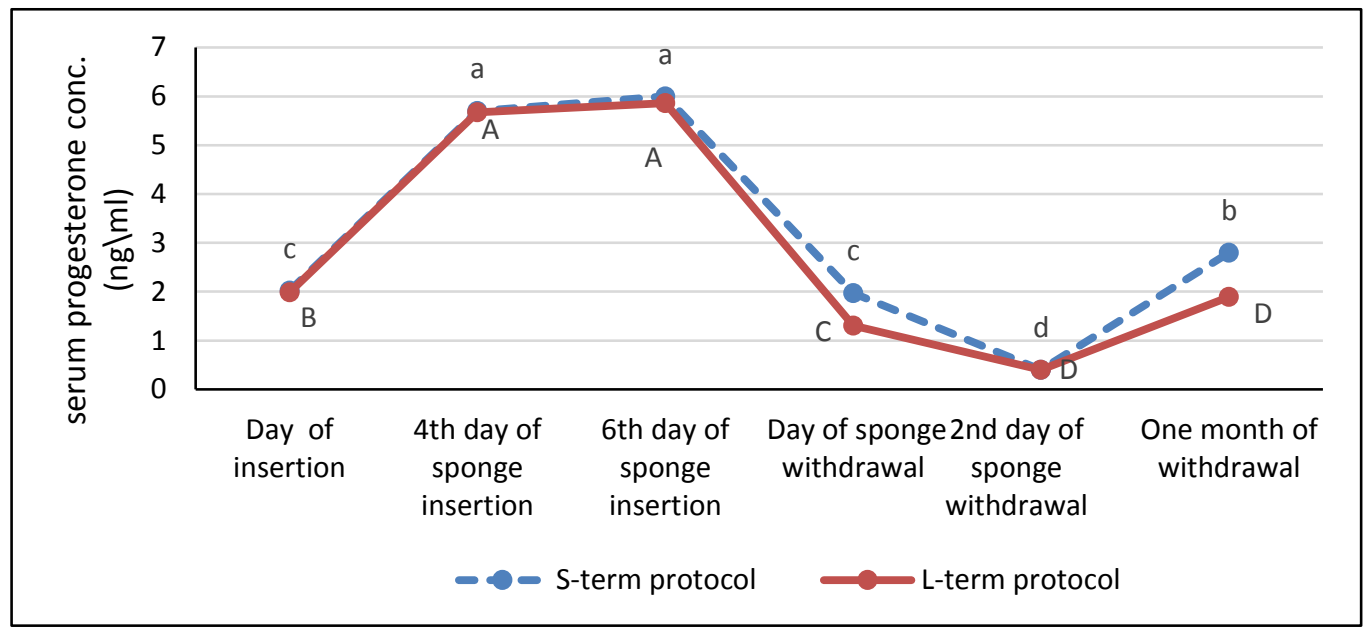

Data with different small and capital letters are significantly different at $(\mathrm{P}<0.05)$

Figure (1): Serum Progesterone levels in Barki ewes during synchronization by short and long term protocols $(n=10)$.

It was found that serum progesterone level was significantly $(\mathrm{P}<0.05)$ higher in $\mathrm{S}$-term protocol group than that in L-term protocol group on day of withdrawal and during the first month after withdrawal $(1.97 \pm 0.08$ vs $1.34 \pm 0.10 \mathrm{ng} / \mathrm{ml})$ and $(2.78 \pm 0.15$ vs $1.89 \pm 0.17 \mathrm{ng} / \mathrm{ml})$, respectively (Table 2).

Table 2: (mean \pm SEM) of serum Progesterone levels (ng\ml) in Barki ewes during synchronization by short and long term protocols $(n=10)$.

\begin{tabular}{ccccccc}
\hline & $\begin{array}{c}\text { Day of } \\
\text { insertion }\end{array}$ & $\begin{array}{c}\mathbf{4}^{\text {th }} \text { day of } \\
\text { insertion }\end{array}$ & $\begin{array}{c}\mathbf{6}^{\text {th }} \text { day of } \\
\text { insertion }\end{array}$ & $\begin{array}{c}\text { Day of } \\
\text { withdrawal }\end{array}$ & $\begin{array}{c}\mathbf{2}^{\text {nd }} \text { day of } \\
\text { withdrawal }\end{array}$ & $\begin{array}{c}\text { One month of } \\
\text { withdrawal }\end{array}$ \\
\hline $\mathbf{S}-$ term & $2.02 \pm 0.07$ & $5.65 \pm 0.23$ & $6.00 \pm .19$ & $1.97 \pm 0.08^{\mathrm{a}}$ & $0.44 \pm 0.06$ & $2.78 \pm 0.15^{\mathrm{a}}$ \\
\hline L- term & $1.99 \pm 0.07$ & $5.67 \pm 0.21$ & $5.86 \pm .24$ & $1.34 \pm 0.10^{\mathrm{b}}$ & $0.40 \pm 0.04$ & $1.89 \pm 0.17^{\mathrm{b}}$ \\
\hline
\end{tabular}

Data with different superscripts within the same column are significantly different at $(\mathrm{P}<0.05)$.

Data presented in Table (3), revealed that there was a non-significant difference between the pattern of serum estradiol level during estrus synchronization between S-term protocol and L-term protocol groups. 
Table 3: (mean \pm SEM) of serum Estradiol levels (pg\ml) in Barki ewes during synchronization by short and long term protocols $(n=10)$.

\begin{tabular}{ccccccc}
\hline & $\begin{array}{c}\text { Day of } \\
\text { insertion }\end{array}$ & $\begin{array}{c}\mathbf{4}^{\text {th }} \text { day of } \\
\text { insertion }\end{array}$ & $\begin{array}{c}\mathbf{6}^{\text {th }} \text { day of } \\
\text { insertion }\end{array}$ & $\begin{array}{c}\text { Day of } \\
\text { withdrawal }\end{array}$ & $\begin{array}{c}\mathbf{2}^{\text {nd }} \text { day of } \\
\text { withdrawal }\end{array}$ & $\begin{array}{c}\text { One month after } \\
\text { withdrawal }\end{array}$ \\
\hline $\mathbf{S}-$ term & $4.63 \pm 0.31$ & $3.31 \pm 0.19$ & $3.63 \pm 0.08$ & $2.90 \pm 0.19$ & $17.03 \pm 0.60$ & $8.60 \pm 0.44$ \\
\hline L- term & $5.21 \pm 0.44$ & $3.31 \pm 0.17$ & $3.28 \pm 0.16 \pm$ & $2.60 \pm 0.22$ & $16.20 \pm 0.79$ & $7.24 \pm .0 .76$ \\
\hline
\end{tabular}

Tables (4, 5 and 6) showed serum levels of total protein, albumin and globulin in S-term protocol group as compared with L-term protocol group. There was non-significant difference between the two groups in all the experimental days in these parameters except in serum globulin level of L-term protocol group at one month after sponge withdrawal which was significantly $(\mathrm{P}<0.05)$ higher than that in $\mathrm{S}$-term protocol group ewes.

Table 4: (mean \pm SEM) of serum Total protein levels (mgldl) in Barki ewes during synchronization by short and long term protocols $(n=10)$.

\begin{tabular}{ccccccc}
\hline & $\begin{array}{c}\text { Day of } \\
\text { insertion }\end{array}$ & $\begin{array}{c}\mathbf{4}^{\text {th }} \text { day of } \\
\text { insertion }\end{array}$ & $\begin{array}{c}\mathbf{6}^{\text {th }} \text { day of } \\
\text { insertion }\end{array}$ & $\begin{array}{c}\text { Day of } \\
\text { withdrawal }\end{array}$ & $\begin{array}{c}\text { 2nd day of } \\
\text { withdrawal }\end{array}$ & $\begin{array}{c}\text { One month after } \\
\text { withdrawal }\end{array}$ \\
\hline S - term & $6.60 \pm 0.10$ & $6.70 \pm 0.10$ & $6.45 \pm 0.13$ & $6.65 \pm 0.10$ & $6.96 \pm 0.13$ & $6.45 \pm 0.20$ \\
\hline L- term & $6.80 \pm 0.16$ & $6.60 \pm 0.16$ & $6.41 \pm 0.16$ & $6.96 \pm 0.10$ & $6.13 \pm 0.10$ & $6.70 \pm 0.16$ \\
\hline
\end{tabular}

Table 5: (mean \pm SEM) of Serum Albumin Levels (mgldl) in Barki ewes during synchronization by short and long term protocols $(n=10)$.

\begin{tabular}{ccccccc}
\hline & $\begin{array}{c}\text { Day of } \\
\text { insertion }\end{array}$ & $\begin{array}{c}\mathbf{4}^{\text {th }} \text { day of } \\
\text { insertion }\end{array}$ & $\begin{array}{c}\mathbf{6}^{\text {th }} \text { day of } \\
\text { insertion }\end{array}$ & $\begin{array}{c}\text { Day of } \\
\text { withdrawal }\end{array}$ & $\begin{array}{c}\text { 2nd day of } \\
\text { withdrawal }\end{array}$ & $\begin{array}{c}\text { One month after } \\
\text { withdrawal }\end{array}$ \\
\hline $\mathbf{S}-$ term & $3.78 \pm 0.10$ & $3.55 \pm 0.13$ & $3.42 \pm 0.15$ & $3.30 \pm 0.13$ & $3.18 \pm 0.10$ & $3.53 \pm 0.10$ \\
\hline L- term & $3.85 \pm 0.06$ & $3.55 \pm 0.10$ & $3.30 \pm 0.08$ & $3.59 \pm 0.13$ & $3.28 \pm 0.13$ & $3.58 \pm 0.10$ \\
\hline
\end{tabular}

Table 6: (mean \pm SEM) of serum Globulin levels (mgldl) in Barki ewes during synchronization by short and long term protocols $(\mathrm{n}=10)$.

\begin{tabular}{ccccccc}
\hline & $\begin{array}{c}\text { Day of } \\
\text { insertion }\end{array}$ & $\begin{array}{c}\mathbf{4}^{\text {th }} \text { day of } \\
\text { insertion }\end{array}$ & $\begin{array}{c}\mathbf{6}^{\text {th }} \text { day of } \\
\text { insertion }\end{array}$ & $\begin{array}{c}\text { Day of } \\
\text { withdrawal }\end{array}$ & $\begin{array}{c}\mathbf{2}^{\text {nd }} \text { day of } \\
\text { withdrawal }\end{array}$ & $\begin{array}{c}\text { One month after } \\
\text { withdrawal }\end{array}$ \\
\hline $\mathbf{S}-$ term & $2.91 \pm 0.16$ & $3.21 \pm 0.15$ & $2.93 \pm 0.93$ & $3.35 \pm 0.10$ & $3.03 \pm 0.14$ & $2.50 \pm 0.13^{\mathrm{b}}$ \\
\hline L- term & $3.4 \pm 0.19$ & $2.95 \pm 0.16$ & $3.1 \pm 0.18$ & $3.57 \pm 0.16$ & $2.9 \pm 0.19$ & $3.24 \pm 0.18^{\mathrm{a}}$ \\
\hline
\end{tabular}

Data with different superscripts within the same column are significantly different at $(\mathrm{P}<0.05)$.

Serum GPX levels on the day of sponge insertion, $4^{\text {th }}$ day of insertion, $6^{\text {th }}$ day of insertion, day of sponge withdrawal, $2^{\text {nd }}$ day of withdrawal and after one month of withdrawal in S-term protocol group as compared to L-term protocol group were represented in Table (7). There were non-significance differences between the S-term protocol and L-term protocol groups in the different days of the trial. 
Table 7: (mean \pm SEM) of serum GPX levels $(\mu \mathrm{M} \backslash \mathrm{ml})$ in Barki ewes during synchronization by short and long term protocols $(n=10)$.

\begin{tabular}{ccccccc}
\hline & $\begin{array}{c}\text { Day of } \\
\text { insertion }\end{array}$ & $\begin{array}{c}4^{\text {th }} \text { day of } \\
\text { insertion }\end{array}$ & $\begin{array}{c}\mathbf{6}^{\text {th }} \text { day of } \\
\text { insertion }\end{array}$ & $\begin{array}{c}\text { Day of } \\
\text { withdrawal }\end{array}$ & $\begin{array}{c}\mathbf{2}^{\text {nd }} \text { day of } \\
\text { withdrawal }\end{array}$ & $\begin{array}{c}\text { One month after } \\
\text { withdrawal }\end{array}$ \\
\hline $\mathbf{S}$ - term & $4.14 \pm 0.25$ & $4.45 \pm 0.28$ & $4.2 \pm 0.25$ & $3.88 \pm 0.16$ & $3.15 \pm 0.09$ & $6.65 \pm 0.16$ \\
\hline $\mathbf{L}-$ term & $4.18 \pm 0.22$ & $4.05 \pm 0.22$ & $3.88 \pm 0.25$ & $4.02 \pm 0.25$ & $3.10 \pm 0.16$ & $6.47 \pm 0.28$ \\
\hline
\end{tabular}

Serum MDA levels of S-term protocol and L-term protocol groups on the different experimental days were represented in Figure (2). It was observed that the lowest level of MDA of both experimental groups was on the day of sponge insertion which was significantly lower $(\mathrm{P}<0.05)$ than the other experimental days. In S-term protocol group MDA serum levels were significantly decreased $(\mathrm{P}<0.05)$ on the $2^{\text {nd }}$ day of sponge withdrawal and one month after sponge withdrawal than its levels on the $4^{\text {th }}$ and the $6^{\text {th }}$ days of sponge insertion and on the day of sponge withdrawal. Meanwhile, at one month after sponge withdrawal its level did not differ significantly than that on the $2^{\text {nd }}$ day of sponge withdrawal and the day of sponge insertion. L-term protocol group showed significant $(\mathrm{P}<0.05)$ increase on the $2^{\text {nd }}$ day of sponge withdrawal than that on the day of sponge insertion, the $6^{\text {th }}$ day of insertion and after one month of sponge withdrawal. Meanwhile, there was non- significance difference between the $4^{\text {th }}$ day of sponge insertion and the day of sponge withdrawal. Also, there was nonsignificance difference between the $6^{\text {th }}$ day of insertion and at one month after withdrawal.

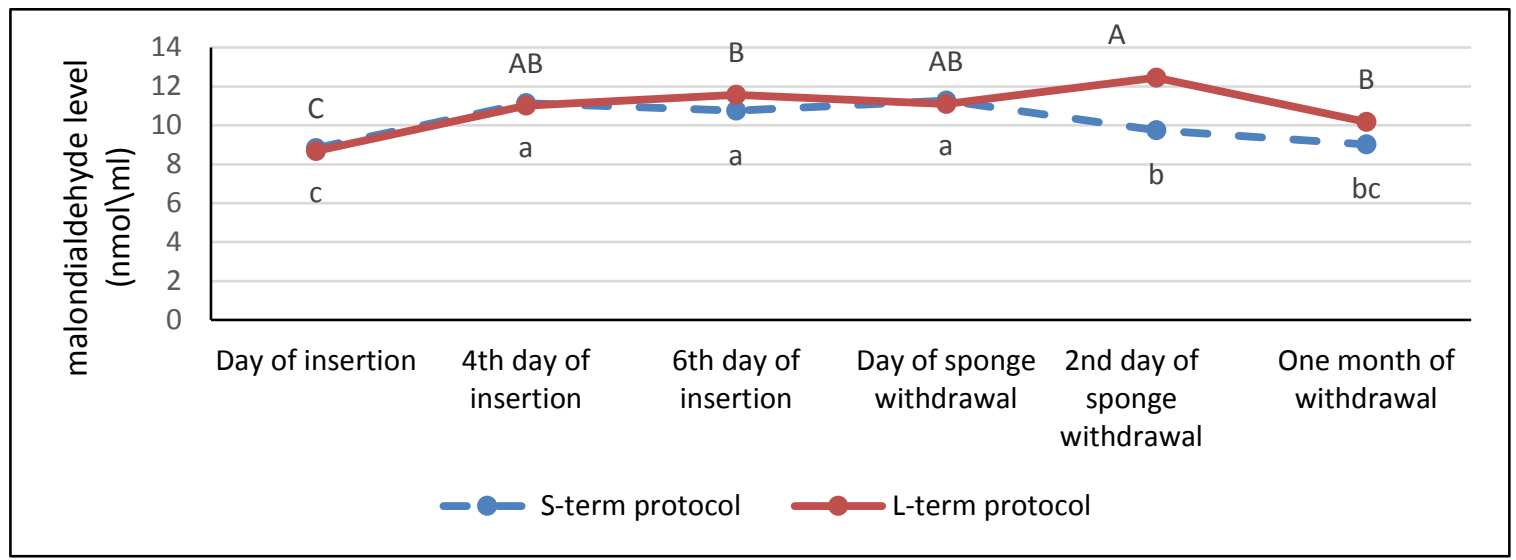

Data with different small and capital letters are significantly different at $(\mathrm{P}<0.05)$.

Figure (2): Serum malondialdehyde levels in Barki ewes during synchronization by short and long term protocols $(\mathrm{n}=10)$.

Serum MDA Levels on day of insertion and on the $4^{\text {th }}$ and the $6^{\text {th }}$ days of insertion; on the day of sponge withdrawal as well as at one month after sponge withdrawal between S-term protocol and L-term protocol groups were illustrated in Table (8), There was a significance decrease $(\mathrm{P}<0.05)$ in serum MDA level on $2^{\text {nd }}$ day of withdrawal and at one month after withdrawal in S-term protocol group ewes than that of L-term protocol group $(9.75 \pm 0.25,12.45 \pm 0.54$ and $9.02 \pm 0.22,10.17 \pm 0.25)$, respectively. Meanwhile, there was non-significance different between the two groups in the other days of the experiment.

Table 8: (mean \pm SEM) of Serum MDA levels in Barki ewes during synchronization by short and long term protocols $(n=10)$.

\begin{tabular}{ccccccc}
\hline & $\begin{array}{c}\text { Day } \\
\text { insertion }\end{array}$ & $\begin{array}{c}\mathbf{4}^{\text {th }} \text { day of } \\
\text { insertion }\end{array}$ & $\begin{array}{c}\mathbf{6}^{\text {th }} \text { day of } \\
\text { insertion }\end{array}$ & $\begin{array}{c}\text { Day of } \\
\text { withdrawal }\end{array}$ & $\begin{array}{c}\mathbf{2}^{\text {nd }} \text { day of } \\
\text { withdrawal }\end{array}$ & $\begin{array}{c}\text { One month after } \\
\text { withdrawal }\end{array}$ \\
\hline S - term & $8.83 \pm 0.41$ & $11.13 \pm 0.34$ & $10.76 \pm 0.28$ & $11.27 \pm 0.33$ & $9.75 \pm 0.25^{\mathrm{b}}$ & $9.02 \pm .0 .22^{\mathrm{b}}$ \\
\hline L- term & $8.68 \pm 0.25$ & $11.01 \pm 0.51$ & $10.56 \pm 0.44$ & $11.09 \pm 0.47$ & $12.45 \pm 0.54^{\mathrm{a}}$ & $10.17 \pm .0 .25^{\mathrm{a}}$ \\
\hline
\end{tabular}

Data with different superscripts within the same column are significantly different at $(\mathrm{P}<0.05)$. 


\section{DISCUSSION}

With regard to serum $\mathrm{P}_{4}$, in the present study, the difference in serum progesterone levels at day of sponge insertion before treatment between S-term protocol group and L-term protocol group were nonsignificant $(2.02$ vs $1.99 \mathrm{ng} / \mathrm{ml})$, respectively; however, the present finding is lower than those reported by Mohan, (2017) in ewes; and Kusina et al. (2000) in goat which may be related to the different stages of the estrous cycle of the experimental animals used in these studies and our study. After initiation of experimental protocol there is a significant increase $(\mathrm{P}<0.05)$ in progesterone level in the two experimental groups till reach the peak level on the $4^{\text {th }}$ day till the $6^{\text {th }}$ day of sponge insertion, the present significant increase $(\mathrm{P}<0.05)$ might be due to the insertion of sponge which are resulted in sustained and slow release of progesterone during the period of its retention in vagina. Similar trend of increasing progesterone levels after vaginal sponge insertion were also reported by Hamra et al. (1986) who stated that progesterone concentration started to increase to near maximum levels within $24 \mathrm{~h}$ after sponge insertion in ewes synchronized with vaginal sponge, reached highest levels on day 4 and then declined. Kusina et al. (2000), also stated that plasma progesterone concentration increases sharply in does treated with intravaginal sponges, following insertion of sponge to reach $(6.0-7.0 \mathrm{ng} / \mathrm{ml})$ within 3-5 days after sponge insertion and this level are maintained thereafter until removal of sponge, then fall sharply to basal level after removal of sponges to reach a level which was less than $(2.0 \mathrm{ng} / \mathrm{ml})$ within $24 \mathrm{hrs}$. The elevation of progesterone level after insertion of vaginal sponge suggest that endogenous progesterone level were augmented indicating intravaginal delivery of progesterone via sponges cause effective and maintained elevated progesterone concentration during the duration of the experiment which is in accordance with the observation made by Kusina et al. (2000).

In sheep and goats, It was found that, the insertion of progesterone impregnated intravaginal device results in a rapid increase in blood progesterone concentrations within two days to reach $(\simeq 5.0 \mathrm{ng} / \mathrm{ml})$, and remain in a constant high level for approximately (4-5) days of treatment (Menchaca and Rubianes, 2004), similar to those levels observed during medium-late luteal phase. However, after 6 or 7 days of treatment, blood progesterone concentrations decrease gradually with time during the remaining period (Husein and kridi, 2002; Yavuzer, 2005) to sub-luteal levels (< $2.0 \mathrm{ng} / \mathrm{mL})$, which enough for blocking ovulation but predisposing to a persistent growth of the dominant follicle, prolonged luteal function and reduced fertility (Johnson et al., 1996). If the intravaginal device is maintained during (12 or 14) days, the detrimental conditions of low progesterone levels described above are present during an excessive period, and then fertility is affected. For this reason, with the aim to promote the follicular turnover and thus allow the ovulation of a young follicle and a healthy oocyte with good fertility, the treatments for estrus synchronization should avoid the exposure to low levels of progesterone during an excessive period.

Progesterone level was significantly $(\mathrm{P}<0.05)$ decreased on the day of sponge withdrawal $\left(7^{\text {th }}\right.$ and $12^{\text {th }}$ day of sponge insertion) in S-term protocol and L-term protocol groups respectively, meanwhile, its level was significantly $(\mathrm{P}<0.05)$ higher in $\mathrm{S}$-term protocol group than that in L-term protocol group on withdrawal day. After that it continued decreasing tell reach minimal level on the $2^{\text {nd }}$ day of sponge withdrawal in the two groups, after that it began to increase during one month after sponge withdrawal due to the conception of ewes. These results were in accordance with Naderipour et al. (2012) who reported that there was a significant $(\mathrm{P}<0.05)$ decrease in the level of progesterone in both the experimental and control group on the day of estrus, when compared with the initial concentration before initiation of any synchronization treatment.

Concerning serum estradiol levels data analysis revealed that its average levels on day of sponge insertion in S-term protocol group and L-term protocol group were difference. This difference between the two groups in estradiol concentration on day of sponge insertion may be related to the different stages of the estrous cycle of the experimental animals used in this study. After sponge insertion it decreased and remained low with no significant variation thereafter until the day of withdrawal in the two groups, similar values were also reported by (Cleeff et al., 1998, Naderipour et al., 2012 and Najafi et al., 2014) in ewes. The abrupt decrease in serum estradiol levels after sponge insertion probably may be as a result of high $\mathrm{P} 4$ concentration which inhibit FSH thus prevent development of ovarian follicles which responsible for estrogen synthesis (Noor Hashida et al., 2013). After that its level was increased sharply following withdrawal of the sponge and reaches its peak values on the $2^{\text {nd }}$ day of withdrawal for S-term protocol group and L-term protocol group. These results in agreement with Vinoles et al. (2001) who found that maximum serum estradiol level was detected after sponge withdrawal in ewes and with Kausar et al., 2005 and Blaszczyk et al., 2004), who found an estradiol peak values of between $(9.0$ and $16.0 \mathrm{pg} / \mathrm{ml})$ in goat. This sharp increase in serum estradiol level on the $2^{\text {nd }}$ day of sponge withdrawal (pre-ovulatory peak) is an indicator of increase in the number of large follicles, as the number of large follicles and serum estradiol concentrations were positively correlated during the estrus cycle ( $\mathrm{Yu}$ et al., 2005). Also, estradiol level is considered as a good marker of follicular quality (Campbell et al., 1995). Also, Vinoles et al. (2001); 
Ataman et al. (2006) and Oliveira et al. (2015) reported that short-term sponge applications have produced good results in establishing oestrus for ewes both in and out of the breeding season which in agreement with our results. After conception and during the $1^{\text {st }}$ month of pregnancy Estradiol concentration declined to its normal basal value for Sterm protocol and L-term protocol groups, these results in accordance with (Khanum et al., 2008), in goat.

In respect to conception and lambing rates, pregnancy was diagnosed by ultrasonography one month after sponge withdrawal and natural mating. Data analysis revealed that, conception and lambing rates were significantly higher $(\mathrm{P}<0.05)$ in $\mathrm{S}$-term protocol group (90\%) than that in L-term protocol group (60 $\%$ ). This is in accordance with the study by (Vinoles et al., 2001; Ungerfeld and Rubianes, 2002; Papadopoulos et al., 2017), where a higher pregnancy rate was obtained after short-term treatment compared to the traditional long-term (12 d) treatment with PMSG injection at the time of vaginal sponge withdrawal. The reasons for this might be attributable to the sub-luteal serum progesterone concentration observed during the few days at the end of the longterm treatment with progesterone (Gaston-Parry et al., 1988; Viñoles et al., 1999) leads to LH surge and ovulation did not occur, increasing the size of the dominant follicle and turning it into a persistent follicle (Adams, 1999; Vinoles et al., 1999; Menchaca and Rubianes, 2004; Ozyurtlu et al., 2011), and the presence of aged follicles (Johnson et al., 1996), and thus the quality is compromised due to the "aging" of the oocyte within the follicle. Most of these oocytes fail to fertilize with subsequent detrimental effects on pregnancy rate (Viñoles et al., 2001), or have a delay in the development of the zygotes with higher incidence of embryonic death at 2 to 16-cell stage (Ahmad et al., 1995).

Also, Manes et al. (2014) found that using progesterone impregnated vaginal sponge for (13 days) for estrous synchronization, reduced conception rate in comparison with those ewes that did not receive a sponge. Thus, the local effect of the sponge in this case (at least for the long treatment) negatively affected fertility. The sponge as a foreign body induces changes in the normal vaginal environment that favors bacterial growth (Manes et al., 2010) that could have a direct effect on sperm fertilization ability. Although, the number of vaginal bacteria returns to basal values at the time of insemination (Suárez et al., 2006, Gatti et al., 2011 and Mohamed et al., 2017) but changes in the normal vaginal flora composition such as the presence of opportunistic Enterobacteriaceae family were incriminated as a cause of vaginitis in even (72 h) after device removal (Manes et al., 2010; Martins et al., 2009). On the same hand, Gatti and Ungerfeld (2012) found that the use of progesterone impregnated intravaginal sponges for 14 days negatively affected ewes' sexual attractiveness, but this decrease was not mitigated by inclusion of a local antibiotic.

The obtained results declared that, values of serum total protein levels showed a non- significant change in serum total protein levels on all days of the experiment from sponge insertion till the day of sponge withdrawal and to one month after withdrawal in S-term protocol and L-term protocol groups. These results agreed well with Arya, (2008) who suggested that there was no effect of progesterone with PMSG and HCG administration on the blood serum protein. In the opposite of that, other workers reported that serum total protein levels were significantly higher during estrus as compared with that levels before estrus (Murthy and Rao, 1981) in ewes, and (Ishwar and Pandy, 1994) in goat which may be resulted from increased metabolic activity while the females were under the influence of higher levels of estrogen. In contrary to that result, several workers reported that serum total protein levels in ewes were significantly decreased during follicular phase of estrous cycle (Wani et al., 2018 and Ibrahim et al., 1984). Walmer et al. (1992) explained the changes in total protein as follow the decrease in serum total protein may be due to increase in blood flow to the uterus during the estrus phase. In respect to the change of serum total protein levels between S-term protocol and L-term protocol groups the obtained results revealed that there were a non-significant difference between them in serum total protein levels.

The obtained data did not show any significant variations in serum albumin levels at all days of the experiment in each of the S-term protocol and L-term protocol groups or even between the two groups. These results somewhat in accordance with Wani et al. (2018) who published that there was a nonsignificant increase in serum albumin level of ewes that was applicated by progesterone vaginal sponge during both follicular phase and luteal phase. In the contrary Murthy and Rao (1981) suggested that albumin levels in ewes were significantly higher $(\mathrm{P}<0.01)$ during estrus. Also, Piccione et al. (2009) who found that serum total protein and albumin significantly increased in pregnancy than in diestrus in ewes.

Data analysis recorded a non-significant change of serum globulin levels between S-term protocol and Lterm protocol groups during the trial except after one month after sponge removal and breeding of the ewes there was a significant decrease in S-term protocol group than that in L-term protocol group; these results may be explained by the results that obtained by Hassanein et al. (1999) who suggested that, progesterone synthesis may enhance the activation of membrane bound adenyl cyclase which causes an increase in the intracellular concentration of C.AMP 
that may act at the cytoplasmic level to stimulate protein synthesis.

Regarding to serum GPX levels, there was a nonsignificant difference in comparing GPX levels of the two protocols. Meanwhile, the obtained results revealed that serum MDA levels recorded a significant decrease $(\mathrm{P}<0.05)$ in the day of sponge insertion than the other experimental days in both $\mathrm{S}$ term protocol and L-term protocol groups. However, data are not available to indicate how GPX and MDA concentrations are affected by the stage of estrous cycle, some authors as (El-Shahat and Kandil, 2012) explained the changes of oxidant-antioxidant status as follow, the high MDA concentrations recorded in serum at estrus which may be attributed to an increase in the production of Reactive Oxygen Species (ROS), these ROS were suggested to originate mainly from steroidogenesis occurring in granulosa cells. While, Heba et al. (2014) mention that serum MDA and TAC levels were significantly higher during luteal phase than follicular phase in summer which may due to seasonal variations.

Also, Mohebbi-Fani et al. (2012) found that oxidative stress increases during early pregnancy because of high metabolic rate of the placenta and increased generation of ROS and may be linked to foetal programming.

The most significant and striking findings in the current experiment were the MDA results which showed a significant increase at the $2^{\text {nd }}$ day of sponge withdrawal (follicular phase) and at one month after sponge withdrawal and mating (the first month of pregnancy) in L-term protocol group than that in Sterm protocol group which could indicate a continuous lipid peroxidation due to oxidative stress in this period in L-term protocol group, this may be the cause of low conception rate in this group. This oxidative stress may be occur due to an imbalance between the ROS and the antioxidant defenses which has been identified to play a key role in the pathogenesis of subfertility in females which in agreement with that determined by (AL-Gubory et al., 2005).

Also, these results may explained by Behrman et al. (2001) who mentioned that ROS are generated in follicles due to oocyte maturation and ovulation and in luteal tissue during natural regression to inhibit steroidogenesis. Adequate placental antioxidant status is essential for proper placental function and development and its effectiveness against oxidative stress varies with the stage of placental development in sheep (Garrel et al., 2010). Naziroglu et al. (2004) also found that plasma MDA was negatively affected on day 20 of pregnancy in rats.

Research in oxidant-antioxidants status at different synchronization protocols is almost non-existent and therefore more research is needed in the future to elucidate the precise mechanisms through which oxidative stress affects female reproductive abilities, and will facilitate further explorations of the better and more useful method of synchronization protocols.

\section{CONCLUSION}

This study revealed that the short-term progestagen treatment for oestrus synchronization protocol (7 days) could be applied in Barki ewes during the breeding season, it is more preferable and a good alternative in the field than the traditional long term protocol (12 days); as it is offering a better fertility, higher conception rate, reduce tasks and time as well as labor management leading to higher performance in the farm condition and facilitate crop marketing.

\section{ACKNOWLEDGEMENT}

We would like to appreciate Dr. Abdel Karim Mahmoud Aish (ultrasonography unit in ARRI) who provided help and support during sonar examinations. Also, I would like to extend a huge thank you to Dr. Tarek Abdel Salam Hassan (Professor of physiology, Biology department, ARRI) for his guidance in review the writing part of the research.

\section{REFERENCES}

Abecia, J.A.; Forcada, F. and Gonzalez-bulnes, A. (2012): Hormonal control of reproduction in small ruminants. Anim Reprod Sci.; 130: 173179.

Adams, G.P. (1999): Comparative patterns of follicle development and selection in ruminants. J. Reprod. Fertil.; 54:17-32.

Ahmad, N.; Schrick, R.; Butcher, S. and Inskeep, E. (1995): Effect of persistent follicles on early embryonic losses in beef cows. Biol. Reprod., 52: 1129-1135.

AL-Gubory, K.H.; Ceballos-Picot, I.; Nicole, A.; Bolifraud, P.; Germain, G.; Michaud, M.; Mayeur, C. and Blachier, F. (2005): Changes in activities of superoxide dismutase, nitric oxide synthase, glutathione-dependent enzymes and the incidence of apoptosis in sheep corpus luteum during the estrous cycle. Biochem. Biophys. Acta - General Subjects, 1725, 348-357.

Ali A. (2007): Effect of time of eCG administration on follicular response and reproductive performance of FGA-treated Ossimi ewes. Small. Rumin. Res. 72: 33-37.

Arya G.K. (2008): Effect of different doses of injectable progesterone on synchronization of estrus and fertility in Goats. Master of Veterinary Science (Veterinary Physiology) of the Faculty of Post-Graduate Studies, Birsa Agricultural University, Ranchi (Jharkhand). 
Ataman, M.B.; Akoz, M. and Akman, O. (2006): Induction of synchronized +oestrus in Akkaraman cross-bred ewes during breeding and anestrus seasons the use of short-term and long-term progesterone treatments. Rev. Med. Vet. 157(5): 257-260.

Ayo, J.O.; Oladele, S.B. and Fayomi, A. (1996): Effects of heat stress on livestock production: A review. Nigeria Vet. J., 1: 58-68.

Behrman, H.R.; Kodaman P.H.; Preston, S.L. and Gao, S. (2001): Oxidative stress and the ovary. J. Soc. Gynecol. Invest., 8, S40-S42.

Blaszczyk, B.; Udala, J. and Gaczarzewicz, D. (2004): Changes in estradiol, progesterone, melatonin, prolactin and thyroxin concentrations in blood plasma of goats following induced estrus in and outside the natural breeding season. Small Rumin. Res., 51: 209-219.

Campbell, B.K., Scaramuzzi, R.J. and Webb, R. (1995): Control of antral follicle development and selection in sheep and cattle. J. Reprod Fertil 1995; 49: 335-350.

Cleeff, J.V.; Karsch, F.J. and Padmanabhan, V. (1998): Characterization of endocrine events during the periestrous period in sheep after estrous synchronization with controlled internal drug release (CIDR) device. Domest Anim Endocrinol., 15(1): 23 -34.

Dobson, H.; Fergani, C.; Routly, J.E. and Smith, R.F. (2012): Effects of stress in reproduction in ewes. Anim. Reprod. Sci., 130: 135-140.

Doumas, B.T.; Watson, W.A. and Biggs, H.G. (1971): Albumin standers and the measurements of serum albumin with bromcresol green. Clin. Chim. Acta. 31: 87-96.

Doumas, B.T.; Bayse, D.D. and Carter, R.J. (1981): Candidate reference method for determination of total protein in serum. I. Development and validation, II. Tests for transferability. Clin. Chem. 27: 1642-1654.

Eckersall, P.D. (2008): Proteins, proteomics, and the dysproteinemias. In: Kaneko JJ, Harvey JW, Bruss ML (eds): Clinical Biochemistry of Domestic Animals. $6^{\text {th }}$ ed n. El-Sevier Academic Press, California 117-155.

El-Shahat, KH. and Kandil, M. (2012): Antioxidant capacity of follicular fluid in relation to follicular size and stage of estrous cycle in buffaloes. Theriogenology2012; 77(8): 15131518.

Evans, A.C.O.; Flynn, J.D.; Quinn, K.M.; Duffy, P.; Quinn, P.; Madgwick, S.; Crosby, T.F.; Boland, M.P. and Beard, A.P. (2001): Ovulation of aged follicles does not affect embryo quality or fertility after a 14-day progestagen estrus synchronization protocol in ewes. Theriogenology, 2001, 56, 923-936.

Fuquay, J.W. (1981): Heat stress as it affects animal production. J. Anim. Sci., 52: 164-174.
Garrel, C.; Fowler, P.A. and Al-Gubory, K.H. (2010): Developmental changes in antioxidant enzymatic defence against oxidative stress in sheep placentomes. J. Endocrinol., 205, 107116.

Gaston-Parry, O.; Heasman, K.; Nemorin, J.K.E. and Robinson, T.J. (1988): A radioimmunoassay for flurogestone acetate (FGA) and its application to the measurement of plasma FGA and progesterone in ewes treated with FGA-impregnated intravaginal sponges. Aust. J Biol. Sci. 41: 57-67.

Gatti, M. and Ungerfeld, R. (2012): Intravaginal sponges to synchronize estrus decrease sexual attractiveness in ewes. Theriogenology 78 (2012) 1796-1799.

Gatti, M.; Zunino, P. and Ungerfeld, R. (2011): Changes in the aerobic vaginal bacterial mucous load after treatment with intravaginal sponges in anestrous ewes: Effect of medroxy progesterone acetate and antibiotic treatment use. Reprod Dom Anim2011; 46: 205-208.

Gomez, J.D.; Balasch, S.; Gomez, L.D.; Martino, A. and Fernandez, N. (2006): A comparison between intravaginal progestagen and melatonin implant treatments on the reproductive efficiency of ewes. Small Rumin. Res., 66: 156-163.

Hamra, A.H.; Massri, Y.G.; Marcek, J.M. and Wheaton, J.E. (1986): Plasma Progesterone levels in ewes treated with progesterone controlled internal drug release dispensers, implants and sponges. Animal Reproduction Science 1986; 11: 187-194.

Hassanein, M.R.R.; Hussein, S.A. and Hayat, H. ELNour (1999): Some Biochemical Studies during estrous cycle and after synchronization in Barki ewes. The Egyptian Journal of Biochemistry; 17 (2) 281-299

Heba F. Hozyen; Hodallah H. Ahmed; Essawy, G.E.S. and Shalaby, S.I.A. (2014): Seasonal changes in some oxidant and antioxidant parameters during folliculogenesis in Egyptian buffalo. Journal of Endodontics, Volume 151, Issues 3-4, Pages 131-136.

Husein, M.Q.; Abebneh, M.M. and Abu-Ruman, D.S. (2007): The effects of short or long term FGA treatment with or without eCG on reproductive performance of ewes bred out-of-season. Am. J. Anim. Vet. Sci. 2(1): 23-28.

Husein, M.Q. and kridi, R.T. (2002): reproductive responses of Awassi ewes treated with either naturally occurring progesterone or synthetic progestagen. Asian-Australian J. Anim. Sci. 9: $1257-1262$

Ibrahim, H.; Gomaa, A. and serur, B.H. (1984): Some biochemical changes in the blood serum of ewes during estrous and diestrus. J. Egypt, Vet. Med. Ass. 44(2): 41.

Ishwar, A.K. and Pandey, J.N. (1994): Estrus synchronization and fertility behaviour in 
Black Bengal goats following progesterone or prostaglandin treatment. Theriogenology, 34: 1015-1024.

Johnson, S.K.; Dailey, R.A.; Inskeep, E.K. and Lewis, P.E. (1996): Effect of peripheral concentrations of progesterone on follicular growth and fertility in ewes. Dom. Anim. Endocrin., 13, 69-79.

Khanum, S.A.; Hussain, M. and Kausar, R. (2008): Progesterone and estradiol profiles during estrous cycle and gestation in Dwarf goats (Capra Hircus) Pakistan Vet. J., 28(1): 1-4.

Kusina, N.T.; Tarwirei, F.; Hamudikuwanda, H.; Agumba, G. and Mukwena, J. (2000): A comparison of the effects of progesterone sponges and ear Implants, pgf2alpha, and their combination on efficacy of estrus Synchronization and fertility of mashona goat does. Theriogenology 53, 1567-1580.

Kausar, R.; Khanum, S.A. and Hussain, M. (2005): Characterization of endocrine events at oestrus in Dwarf goat (Capra Hircus) Pakistan Vet. J., 25(3): 143-145.

Manes, J.; Hozbor, F.; Alberio, R. and Ungerfeld, R. (2014): Intravaginal placebo sponges affect negatively the conception rate in sheep. Small Rumin. Res, 120, 108-111.

Manes, J.; Fiorentino, M.A.; Kaiser, G.; Hobor, F.; Alberio, R. and Sanchez, E. (2010): Changes in the aerobic vaginal flora after treatment with different intravaginal devices in ewes. Small Rum. Res.; 94: 201-204.

Martins, G.; Figueira, L.; Penna, B.; Brand, F.; Varges, R. and Vasconcelos, C. (2009): Prevalence and antimicrobial susceptibility of vaginal bacteria from ewes treated with progestin-impregnated intravaginal sponges. Small Ruminant Res.; 10: 1016.

Martin, G.B.; Milton, J.T.B.; Davidson, R.H.; Banchero Hunzicker, G.E.; Lindsay, D.R. and Blache, D. (2004): Natural methods for increasing reproductive efficiency in small ruminants. Anim. Reprod. Sci., 82-83: 231245.

McBurney, M.W.; Yang, X.; Jardine, K.; Hixon, M.; Boekelheide, K.; Webb, J. R.; Lansdorp, P. M. and Lemieux, M. (2002). The Mammalian SIR2 Protein Has a Role in Embryogenesis and Gametogenesis. Molecular and Cellular Biology, 23(1), 38-54.

Menchaca, A. and Rubianes, E. (2004): New treatments associated with Timed Artificial Insemination in small ruminants. Reprod. Fert. Dev., 16, 403- 414.

Mohammed, K.M.; Nabih, A.M. and Darwish, G.M. (2017): Efficacy of anti-microbial agents on vaginal microorganisms and reproductive performance of synchronized estrus ewes, Asian Pacific Journal of Reproduction, $6(3), 121-127$.
Mohan, K.M. (2017): Study of progesterone concentration in EWES synchronized with vaginal sponges. The Pharma Innovation Journal; 6(4): 68-71.

Mohebbi-Fani, M.; Mirzaci, A., Nazifi, S. and Shabbooie, Z. (2012): Changes of vitamins A, $\mathrm{E}$, and $\mathrm{C}$ and lipid peroxidation status of breeding and pregnant sheep during dry seasons on medium-to-low quality forages. Trop Anim Health Prod; 44:259-265.

Murthy, T.S. and Rao, A.V.N. (1981): Blood cholesterol profile of different reproductive phases of graded Murrah buffaloes. Indian Veterinary Journal; 58: 771.

Naderipour, H.; Yadi, J.; Ghazikhani Shad, A. and Sirjani, M.A. (2012): The effects of three methods of synchronization on estrus induction and hormonal profile in Kalkuhi ewes: A comparison study. African Journal of Biotechnology 11: 530-533.

Najafi, G.; Cedden, F. and Maleki, S.A. (2014): The Determination of Plasma Progesterone, Estradiol-17 $\beta$ Hormone Levels in Ghezel Sheep treated with CIDR and Various Doses of PMSG during the Breeding Season. Bull. Env. Pharmacol. Life Sci., Vol 3 [Special Issue, 118-122.

Naziroglu, M.; Simsek, M. and Kutlu, M. (2004): Moderate exercise with a dietary vitamin C and $\mathrm{E}$ combination protects against streptozotocin-induced oxidative damage to the blood and improves fetal outcomes in pregnant rats. Clin. Chem. Lab Med 42: 511517.

Noor Hashida, H.; Syafnir and Meriksa, S. (2013): Time of PMSG administration: Effect on progesterone and estradiol concentration in synchronized ewes. Biomedical Research, 24 (1): 7-12.

NRC (2007): Nutrient Requirements of small Ruminants: Sheep-Goat-Cervids and New World Camelids, $7^{\text {th }}$ Edn. National Academy Press, Washington DC, USA. PP: 221-229.

Ohkawa, H.; Ohishi, N. and Yagi, K. (1979): Assay for lipid peroxides in animal tissues by thiobarbituric acid reaction. Anal. Biochem. Jun; 95(2): 351-58.

Oliveira, M.E.F.; Ayres, H.; Oliveira, L.G.; Barros, F.F.P.C. and Oba, E. (2015): Effects of season and ovarian status on the outcome of long-term progesterone-based estrus synchronization protocols and ovulatory follicle development in Santa Ines ewes under subtropical conditions. Theriogenology. (10), 9-24.

Ozyurtlu, N.; Ay Serhan, S.; Kucukaslan, I.; Gungor, $O$. and Aslan, S. (2011): Effect of subsequent two short-term, short-term, and long-term progestagen treatments on fertility of Awassi ewes out of the breeding season. Ankara Univ. Vet. Fak. Derg. 58, 105-109. 
Pagila, D.E. and Valentine, W.N. (1967): GPX J. Lab. Clin. Med.70: 158-169.

Papadopoulos, S.; Deligiannis, C.; Theodosiadou, E.K.; Kantas D.; Lainas, T.H.; Goulas, P.; Fthenakis, G.C. and Valasi, I. (2017): Fertility rate of short-term progestagen pretreated ewes in relation to breed: A field study. $\mathrm{J}$ HELLENIC VET MED SOC 2017, 68(1): 035-044.

Piccione, G.; Caola, G.; Giannetto, C.; Grasso, F.; Calanni Runzo, S.; Zumbo, A. and Pennisi, P. (2009): $\quad$ Selected biochemical serum parameters in ewes during pregnancy postparturition, lactation and dry period. Animal Science 27:321- 330.

Ratcliffe, W.A.; Canter, G.D. and Donwsett, M. (1988): Estradiol assay: applications and guidelines for the provision of a clinical biochemistry service, Ann. Clin. Biochem. 25: 466-483.

Ross, G.T.; Vande Wiele, R.L. and Frantz, A.G. (1981): The Ovaries and the breasts. In: Williams, R.H., ed., Textbook of Endocrinology. Sanders Company, Philadelphia, 355-411.

Suárez, G.; Zunino, P.; Carol, H. and Ungerfeld, R. (2006): Changes in the aerobic vaginal bacterial mucous load and assessment of the susceptibility to antibiotics after treatment with intravaginal sponges in anestrus ewes. Small Rumin. Res. 63, 39-43.

Swelum, A.A.A.; Alowaimer, A.N. and Abouheif, M.A. (2015): Use of flurogestone acetate sponges or controlled internal drug release for estrus synchronization in ewes: Effects of hormonal profiles and reproductive performance. Theriogenology, 84: 498-503.

Sönmez, M.; Bozkurt, T.; Türk, K.; Gür, S.; Klzıl, M. and Yüce, A. (2009): The effect of vitamin $\mathrm{E}$ treatment during preovulatory period on reproductive performance of goats following estrous synchronization using intravaginal sponges. Anim. Reprod. Sci. 114: 183-192.

Snedecor, G.W. and Cochran, W.G. (1982): In. Statistical Methods, 8th Edition, Iowa state university press, Ames, Iowa-50010.

Ungerfeld, R. and Rubianes, E. (2002): Short term priming with different progestagen intravaginal devices (MAP, FGA and CIDR) for eCG-estrous induction in anestrous ewes. Small Rumin. Res. 46:63-66.

Vinoles, C.; Forsberg, M.; Banchero, G. and Rubianes, E. (2001): Effect of long-term and short-term progestagen treatment on follicular development and pregnancy rate in cyclic ewes. Theriogenology 55: 993-1004.

Viñoles, C.; Meikle, A.; Forsberg, M, and Rubianes, $E$. (1999): The effect of sub-luteal levels of exogenous progesterone on follicular dynamics and endocrine patterns during the early luteal phase of the ewe. Theriogenology, v.51, p.1351-1361.

Walmer, D.K.; Wrone, M. A.; Hughes, C.L., Nelson, K.G., End, (1992): 13: 1458-1466

Wani, J.M.; Sharma, U., Beigh, S.A., Khan, S.A.; Sheikh. A.A., Pandey, A.K.; Wani, N.M.; Ganaie, M.U., Pirzada, A.R. and Haq, Z. (2018): Evaluation of biochemical profile of estrus induced ewes during non-breeding season Journal of Entomology and Zoology Studies; 6(1): 796-799.

Wildeus, S. (1999): Current concepts in synchronizaion of estrus: Sheep and goats. Pro. Am. Soc. Anim. Sci., 1-14.

Whitley, N.C. and Jackson, D.J. (2004): An update on estrus synchronizaion in goats: a minor species. J. Anim. Sci., 82 (Suppl. E), E270E276.

Yavuzer, U. (2005): The possibilities of twice yearly lambing of Awassi sheep ewes without using hormones in an organic animal production system. Turk. J. Vet. Anim. Sci. 29, 27-30.

Yu, Y.S.; Luo, M.J.; Han, Z.B.; Li, W.; Sui, H.S. and Tan, J.H. (2005): Serum and follicular fluid steroid levels as related to follicular development and granulose cell apoptosis during the estrus cycle of goats. Small Rumin Res., 57: 57-65.

Zeleke, M.; Greling, J.P.C.; Schwalbach, L.M.J. and Erasmus, J.A. (2005): Effect of progestagen and PMSG on oestrous synchronization and fertility in Dorper ewes during the transition period. Small Ruminant Research 56(1):4753. 


\section{دراسة مقارنة بين نظامين لتوحيد الشياع طويل المدى وقصير المدى على استجابات الخصوبة فى النعاج البرقي داخل موسم التزاو المدير المدي \\ هوبيا محمد أحمد عبد الرحمن ، مها عبد الحمبا إبراهيم \\ E-mail: maha_doctor2013@yahoo.com Assiut University web-site: www.aun.edu.eg}

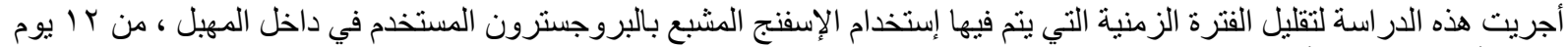

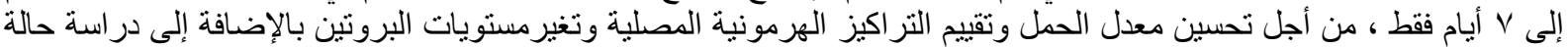

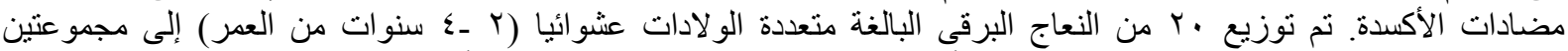

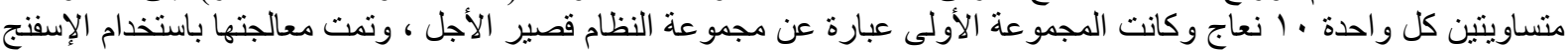

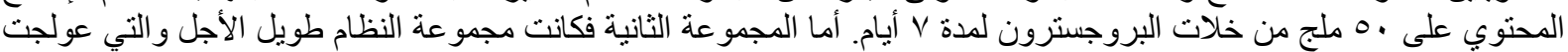

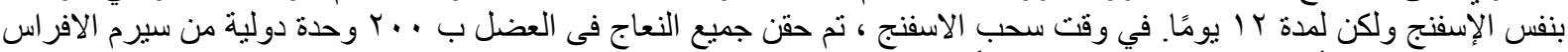

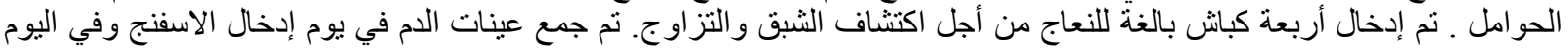

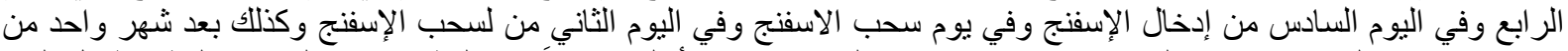

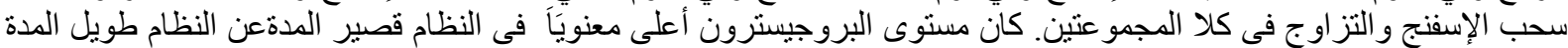

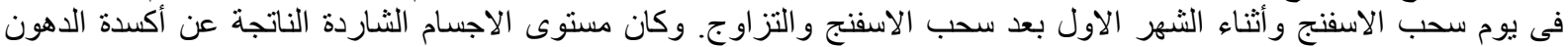

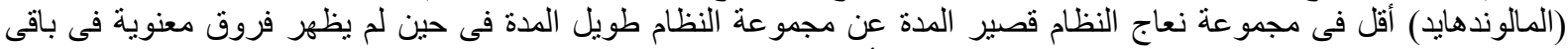

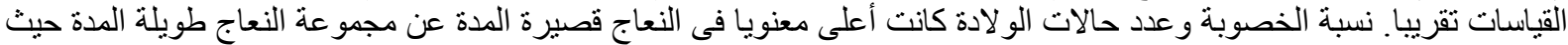

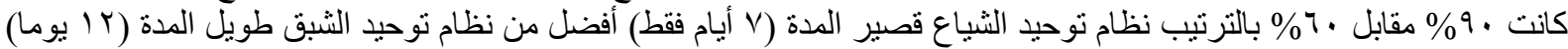

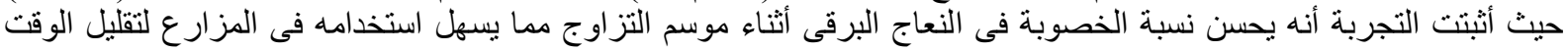
و الجهد وتحسين العائد الاقتصادى. أبه بحن. 